\title{
The Effects of Teat End Hyperkeratosis and Body Dirtiness Scores on Milk Yield and Quality in Holstein-Friesian Cows
}

\section{Frederic Ndihokubwayo and Atakan Koç*}

Aydin Adnan Menderes University, Faculty of Agriculture, Department of Animal Science, 09100, Aydın, Turkey.

Abstract | In this study, the effects of the body dirtiness score (BDS) and teat end hyperkeratosis score (TEHS) on milk yield and quality in Holstein-Friesian (HF) cows were determined. In the study, a total of 432 cows raised in 9 different dairy cattle farms in Aydın Province, Turkey, were inspected. In addition to measure milk yield (MMY, kg), the milk samples were taken from these cows during the morning milking for the determination of fat content (FC, \%), non-fat dry matter content (NFDMC, \%) and somatic cell count (SCC, cell $/ \mathrm{ml}$ ). The means for BDS, TEHS, MMY, FC, NFDMC and $\log _{10}$ SCC were 3.30 $\pm 0.048,2.17 \pm$ $0.038,13.92 \pm 0.315 \mathrm{~kg}, 3.58 \pm 0.039 \%, 10.14 \pm 0.032 \%$ and $5.22 \pm 0.024(165958 \mathrm{cells} / \mathrm{ml})$, respectively. The effects of farm and parity $(\mathrm{P}<0.01)$ on BDS and the effects of farm $(\mathrm{P}<0.01)$, parity $(\mathrm{P}<0.05)$ and lactation stage $(\mathrm{P}<0.01)$ on TEHS and the effects of farm and lactation stage on MMY $(\mathrm{P}<0.01)$ were statistically significant. Considering the milk quality traits, the effect of farm on $\mathrm{FC}(\mathrm{P}<0.01)$; the effects of farm, parity, calving season and lactation stage on NFDMC $(\mathrm{P}<0.01)$ and the effects of farm, parity and TEHS on $\log _{10} \mathrm{SCC}(\mathrm{P}<0.01)$ were found statistically significant. The $\log _{10} \mathrm{SCC}$ positively correlated with the TEHS $(\mathrm{r}=0.24 ; \mathrm{P}<0.01)$, but its correlation with BDS is very low $(\mathrm{r}=0.07 ; \mathrm{P}>0.05)$. As a result, the BDS having no significant effect on milk yield and quality, the regular inspection of the TEHS could contribute to the amelioration of raw milk quality and decrease the SCC level in the milk.

Editor | Muhammad Abubakar, National Veterinary Laboratories, Park Road, Islamabad, Pakistan.

Received | April 18, 2021; Accepted | May 15, 2021; Published | June 07, 2021

*Correspondence | Atakan Koç, Aydın Adnan Menderes University, Faculty of Agriculture, Department of Animal Science, 09100, Aydın, Turkey; Email: akoc@adu.edu.tr

Citation | Ndihokubwayo, F. and A. Koç. 2021. The effects of teat end hyperkeratosis and body dirtiness scores on milk yield and quality in holstein-friesian cows. Veterinary Sciences: Research and Reviews, 7(1): 83-91.

DOI | https://dx.doi.org/10.17582/journal.vsrr/2021.7.1.83.91

Keywords | Dairy cattle, Cow milk, Fat content, Somatic cell count, Correlation

\section{Introduction}

$\mathrm{T}$ The consumption of cow milk is spread worldwide and has a great importance in human nutrition. Unless vegans, everybody is likely to consume cow milk. That act started very earlier after cattle domestication since 10-12 thousand years BC (Butor, 2019). Even though there are more than 800 cattle breeds worldwide, only few breeds are raised for milk production purposes (Akman et al., 2015).
The quantity of harvested milk and its quality are the first priority for milk producers and consumers. That is why the cleanliness of the cow and the healthness of the udder and teats have to be taken into account. The hygienic conditions of the barn and the bedding of cows, once well controlled, help in reducing the proliferation of harmful microorganisms that can colonize the udder entering by the teat canal. The body dirtiness score (BDS) in lactating cow is necessary to assess the quality of the environment. 
Erden and Okuyucu (2019) suggested that cows' hygienic status is of capital importance in ensuring the high quality of raw milk especially in dairy cattle managed in wetlands and muddy areas where the pollution rate is increased. Thus, the milk quality is likely to be affected by that environmental pollution. As solution, the cleaning of the shelter and the provision of clean woodchips are the major solutions to keep cows clean (O'Driscoll et al., 2008). In a study of determining the hygiene score at the udder, rear leg and flanc level, it was found the means 1.77, 2.42 and 1.95 , respectively, in a four based scale of BDS determination (Sandrucci et al., 2014). In another study, it was found 2.76, 2.40 and 2.54 respectively for the udder, real leg and flanc BDS in a four based scale (Dohmen et al., 2010). Furthermore, Erden and Okuyucu (2019) performed a study of determining a hygiene score at the udder, rear leg and flanc levels in dairy cows and calculated 1.57, 2.16 and 1.49 of means, respectively. Once calculated the correlation between the udder hygiene score and the $\log _{10} \mathrm{SCC}$, they found a high correlation coefficient 0.53 that they explained as due to the microorganism invasion related to increased udder dirtiness score related to the reported season effect especially the spring and summer. With the similar interest, Bulu and Erdem (2019) performed a studdy in buffalo. They found a significant lower level of milk constituents in milk samples from buffalo scored 4 of BDS and there were very weak correlation coefficients between milk SCC and udder, rear leg and flanc hygiene scores such as $\mathrm{r}=0.037,0.052$ and 0.016 , respectively. This means that in their study, the SCC in the milk was not influenced by the hygiene score.

In addition, for the health of the udder and the teats in machine milked cows, the control of teat condition, especially the teat end hyperkeratosis, is of great importance. Normally, the state of teat conditions and udder show also the status of the general health of the lactating cow (Ndihokubwayo et al., 2019). The teat condition's deteriorations are caused by factors such as milking machines errors (Baştan, 2010), high vacuum, prolonged milking time, increased milk yield (Mundan et al., 2015), the breed, genetic, cow's age (Sieber and Farnsworth, 1981; Shearn and Hillerton, 1996; Neijenhuis et al., 2001), the parity (Emre, 2009), stage of lactation (Francis, 1984), etc. Thus, there is formation of cracks at the teat end that provoke sphincter cellular degeneration and harmful microorganisms are likely to develop in those cracks. Those pathogens colonize the teat and, via the teat canal, enter into the udder and are susceptible to cause infections in the udder (Blowey and Edmondson, 1995) that result in subclinical or clinical mastitis. So, the control and scoring of the teats may help to determine the intensity of the milk quality deterioration in lactating cows.

Regarding the milk yield, harvested milk depends on the breed, parity, nutrition status, season, lactation stage, lactation month, milking time (morning, evening), etc. Koç (2007a) found $13.20 \pm 0.529 \mathrm{~kg}$ of average in HF cows during morning milking time. Koç (2007b) found $8.92 \pm 0.188 \mathrm{~kg}$ in HF during inspection time milk yield. An average of $10.58 \pm$ $0.204 \mathrm{~kg}$ morning milk yield (MMY) average was found higher when compared to evening milk yield average $(8.99 \pm 0197 \mathrm{~kg}$ ) in $\mathrm{HF}$ cows (Koç and Kizilkaya, 2009). In a study, an average of $7.69 \pm 0.397$ $\mathrm{kg}$ MMY in HF cows was repoted by Koç (2011).

Considering the milk quality traits, some are affected by genetic, environmental and nutritional conditions such as milk fat content (FC), protein content (PC), non-fat dry matter content (NFDMC), lactose content (LC), etc. Study related to milk FC are not in accordance. FC is balanced by the farm management and the nutrition issues within the farm. The great key to get good results in milk FC is to feed cows with $35 \%$ of the ration being forage or forage quantity reaching $1.5 \%$ of body weight. As for the NFDMC, Koç (2007a) conducted a study in HF cows and found an average of $9.98 \pm 0.99 \%$. In another study, Koç (2007b) found $9.61 \pm 0.048 \%$ of average NFDMC in $\mathrm{HF}$ cows. The similar studies were conducted by the same researcher $\operatorname{Koç}(2008,2011,2015)$ and found $9.78 \pm 0.024 \%, 8.23 \pm 0.067 \%$ and $8.78 \pm 0.044 \%$ of milk NFDMC in HF cows, respectively.

Other milk quality traits are influenced by the hygenic conditions and milking management such as the total number of bacteria and somatic cell count (SCC). In accordance to milk SCC, Michel et al. (1974) suggested that the increased teat end hyperkeratosis correlates with the increased mastitis incidence risks. A significant effect of the teat end hyperkeratosis score (TEHS) on SCC was reported and a higher teat hyperkeratosis during the fourth month of lactation and a relationship of the teat end hyperkeratosis with an increased number of SCC was found by Francis (1984). Ng-Kwai-Hang et al. (1984) conducted a 
study aimed at comparing the variation in milk SCC according to the age in two groups of cows and found 166000 cells / $\mathrm{ml}$ of average. Topaloğlu and Güneş (2005) found 138000 cells / $\mathrm{ml}$ of SCC in their study. In the same way, Koç (2009) performed a study aimed at comparing the SCC in the milk of cows that calved in winter by morning and evening milkings and found 133265 cells / ml of average. Y1lmaz (2010) found 63753 cells / ml in Red-Holstein, Koç (2011) found 199022 cells/ml and 138644 cells $/ \mathrm{ml}$, respectively in summer and winter with 168833 cells $/ \mathrm{ml}$ of average in both seasons in $\mathrm{HF}$ and MB cows. Koç (2015) also found 91833 cells/ $\mathrm{ml}$ and 100462 cells/ ml in $\mathrm{RH}$ cows during morning and evening milkings, respectively.

Wether affected by the nutritional or hygienic conditions, the quantity and quality of milk is to be controlled seriously following the long chain from the cow till the table of the consumer. The current study focussed more on the degree of cow's dirtiness and teat end conditions that are susceptible to affect the milk yield and quality and it was aimed at determining the BDS and TEHS effects on milk yield (MMY), milk constituents (FC and NFDMC) and milk quality (SCC) in HF dairy cows.

\section{Materials and Methods}

This study was carried out on HF dairy cows raised in the province of Aydın, Turkey since October, 2019 till February, 2020.

The realisation of this study was approved by the stuff of Aydin Adnan Menderes University, Faculty of Agriculture and samples were taken under the permission of local farmers. Animal ethics and welfare were well respected during the milk samples' harvest, no incomftability or any malease was submitted to animal.

\section{Sample size}

During this study, a total of $432 \mathrm{HF}$ cows raised in 9 different farms were used for the determination of BDS and TEHS during the farm visit. Besides, only 265 cows were used for MMY sampling.

\section{Sample harvest}

A quantity of $50 \mathrm{ml}$ of milk samples was harvested into the sterile container individually from every cow and were transited to the Animal Breeding Laboratory of ADU Faculty of Agriculture, Turkey, for milk quality analysis. Milk samples were collected during morning milking times and were still preserved in the cold chain for the determination of FC, NFDMC and SCC and the laboratory analysis was proceeded without storage. However, it was not possible to measure the milk yield in the morning milking of cows in one farm. Therefore, MMY was evaluated on a total of 265 data obtained from 8 farms in the study. In fact, the BDS was performed by analysing the degree of cleanliness or dirtiness of the udder and the hind legs from the hoof till the tarsal joint and the score 1-5 was used. The TEHS was determined by scoring the teat end hyperkeratosis after milking and the score 1-4 was used (Mein et al., 2001).

\section{Laboratory analysis}

The rate of milk FC was determined using Gerber method (EAS 164, 2006). The NFDMC was determined using a portable refractometer (Brand: ATC Refractometer 0-20\% BRIX) and the SCC was determined by using Direct Microscopic Somatic Cell Count Method (NMC, 1968).

\section{Statistical analysis}

In this study, the statistical analysis was processed with the SAS (1999) package program. Comparison of subgroups was made according to Tukey $(\mathrm{P}<0.05)$. Before the statistical analysis, to ensure homogeneity of variance, the SCC values were transformed using ten based logarithm $\left(\log _{10}\right)$.

The following statistical model was used in the analysis of BDS, TEHS, MMY (kg), FC (\%), NFDMC (\%) and $\log _{10}$ SCC:

$$
Y_{i j k l m n o}=\mu+a_{i}+b_{j}+c_{k}+d_{l}+f_{m}+g_{n}+e_{i j k l m n o} \ldots
$$

Where; $\mathrm{Y}_{\mathrm{ijklmno}}$ : observation value of the properties emphasized, $\mu$ : general average of the traits, $a_{i}$ : effects of farm $(i=1,2,3, . ., 9)$, $b_{j}$ : parity effect $(j=1,2,3,4$ and $5+), c_{k}$ : calving season effect $(\mathrm{k}=$ winter, spring, summer, autumn), $\mathrm{d}_{1}$ : lactation stage effect $(1=1(<100$ d), 2 (101-200 d), 3 (201-300 d), 4 (301-400 d) and 5 $(>400 \mathrm{~d}), \mathrm{f}_{\mathrm{m}}$ : TEHS effect $(\mathrm{m}=1,2,3$ and 4 , this factor is used for the analysis of FC, MMY, NFDMC and $\log _{10} \mathrm{SCC}$ ), $\mathrm{g}_{\mathrm{n}}$ : BDS effect ( $\mathrm{n}=1-2,3,4$ and 5, this factor is used for the analysis of FC, MMY, NFDMC and $\left.\log _{10} \mathrm{SCC}\right), \mathrm{e}_{\mathrm{ijklmn}}$ : refers to random error.

In addition, phenotypic correlation coefficients among 
BDS, TEHS, MMY, FC, NFDMC and $\log _{10} \mathrm{SCC}$ were also calculated.

\section{Results and Discussion}

Least-square means (LSM) and standard errors of body dirtines score (BDS), teat end hyperkeratosis score (TEHS), somatic cell count $\left(\log _{10} \mathrm{SCC}\right)$, nonfat dry matter content (NFDMC, \%), fat content
(FC, \%) and morning milk yield (MMY, $\mathrm{kg}$ ) in $\mathrm{HF}$ dairy cows are presented in Table 1.

Table 1: Least-square means and standard errors of body dirtines score (BDS), teat end score (TEHS), somatic cell count $\left(\log _{10} S C C\right)$, non-fat dry matter content (NFDMC, \%), fat content $(F C$, \%) and morning milk yield (MMY, $\mathrm{kg}$ ) in HF dairy cow.

\begin{tabular}{|c|c|c|c|c|c|c|c|c|}
\hline \multirow[t]{2}{*}{ Factor } & \multicolumn{2}{|r|}{ BDS } & TEHS & \multirow{2}{*}{$\begin{array}{c}\log _{10} S C C \\
\mathbf{X} \pm S_{\bar{x}}\end{array}$} & \multirow{3}{*}{$\begin{array}{c}\text { NFDMC } \\
\bar{X} \pm S_{\bar{X}}\end{array}$} & \multirow{2}{*}{$\frac{\mathbf{F C}}{\bar{X} \pm S_{\bar{X}}}$} & \multicolumn{2}{|r|}{ MMY } \\
\hline & $\mathbf{N}$ & $\bar{X} \pm S_{\bar{X}}$ & $\bar{X} \pm S_{\bar{X}}$ & & & & $\mathrm{n}$ & $\overline{\boldsymbol{X}} \pm \boldsymbol{S}_{\bar{X}}$ \\
\hline Farm & & $* *$ & $* *$ & $* *$ & & $* *$ & & $* *$ \\
\hline 1 & 25 & $2.90 \pm 0.187^{\mathrm{ABCabd}}$ & $2.32 \pm 0.158^{\mathrm{ABab}}$ & $5.65 \pm 0.096^{\mathrm{ABabd}}$ & $10.85 \pm 0.104^{\mathrm{ABa}}$ & $3.97 \pm 0.164^{\mathrm{Aa}}$ & 25 & $12.39 \pm 0.944^{\mathrm{Aa}}$ \\
\hline 2 & 6 & $3.81 \pm 0.370$ ACDace & $1.80 \pm 0.312^{\mathrm{ABab}}$ & $5.46 \pm 0.188$ АBCabc & $=10.05 \pm 0.203^{\text {ACDbde }}$ & $4.21 \pm 0.318^{\mathrm{ABa}}$ & 6 & $13.85 \pm 1.782^{\mathrm{ABCaC}}$ \\
\hline 3 & 38 & $2.84 \pm 0.151^{\mathrm{ABab}}$ & $1.87 \pm 0.127^{\mathrm{Aa}}$ & $5.79 \pm 0.081^{\mathrm{Aa}}$ & $10.88 \pm 0.087^{\mathrm{Ba}}$ & $3.60 \pm 0.137^{\mathrm{Aa}}$ & 38 & $12.86 \pm 0.819^{\mathrm{Aa}}$ \\
\hline 4 & 13 & $2.10 \pm 0.252^{\mathrm{Bb}}$ & $1.95 \pm 0.213^{\mathrm{ABab}}$ & $5.21 \pm 0.137^{\mathrm{BCbc}}$ & $10.63 \pm 0.148^{\mathrm{ABab}}$ & $3.37 \pm 0.232^{\mathrm{ABab}}$ & 13 & $11.59 \pm 1.356^{\mathrm{ABCab}}$ \\
\hline 5 & 27 & $3.69 \pm 0.177 \mathrm{Cc}$ & $2.03 \pm 0.150^{\mathrm{ABa}}$ & $5.25 \pm 0.093 \mathrm{BCc}$ & $9.71 \pm 0.100^{\mathrm{CDde}}$ & $3.63 \pm 0.157^{\mathrm{ABa}}$ & 27 & $7.67 \pm 0.920^{\mathrm{Bb}}$ \\
\hline 6 & 104 & $3.26 \pm 0.097 \mathrm{ACac}$ & $2.11 \pm 0.082^{\mathrm{Aa}}$ & $5.35 \pm 0.056^{\mathrm{BCcd}}$ & $10.04 \pm 0.061^{\mathrm{Cd}}$ & $3.04 \pm 0.095^{\mathrm{Bb}}$ & 104 & $15.18 \pm 0.628^{\mathrm{ACac}}$ \\
\hline 7 & 19 & $3.50 \pm 0.212^{\mathrm{ACac}}$ & $2.05 \pm 0.179 \mathrm{ABab}$ & $5.31 \pm 0.108^{\mathrm{BCcd}}$ & $10.90 \pm 0.117^{\mathrm{Ba}}$ & $3.61 \pm 0.183^{\mathrm{ABab}}$ & 19 & $13.18 \pm 1.044^{\mathrm{ACa}}$ \\
\hline 8 & 167 & $3.49 \pm 0.083^{\mathrm{Ccd}}$ & $2.23 \pm 0.070 \mathrm{ABa}$ & $5.25 \pm 0.046^{\mathrm{Cc}}$ & $9.85 \pm 0.050^{\mathrm{Cd}}$ & $3.73 \pm 0.078^{\mathrm{Aa}}$ & - & - \\
\hline 9 & 33 & $4.64 \pm 0.165^{\mathrm{De}}$ & $2.70 \pm 0.140^{\mathrm{Bb}}$ & $5.37 \pm 0.090 \mathrm{ABCcd}$ & $9.48 \pm 0.098^{\mathrm{De}}$ & $3.67 \pm 0.153^{\mathrm{ABa}}$ & 33 & $17.27 \pm 0.917^{\mathrm{Cc}}$ \\
\hline Parity & & $* *$ & $*$ & $* *$ & $* *$ & NS & & NS \\
\hline 1 & 171 & $3.08 \pm 0.093^{\mathrm{a}}$ & $1.92 \pm 0.079$ & $5.25 \pm 0.054^{\mathrm{Aa}}$ & $10.40 \pm 0.059 \mathrm{Aa}$ & $3.77 \pm 0.092$ & 88 & $12.16 \pm 0.668$ \\
\hline 2 & 107 & $3.25 \pm 0.099 \mathrm{ab}$ & $2.16 \pm 0.084$ & $5.38 \pm 0.054^{\mathrm{ABab}}$ & $10.36 \pm 0.058^{\mathrm{Aac}}$ & $3.64 \pm 0.091$ & 71 & $13.04 \pm 0.625$ \\
\hline 3 & 62 & $3.52 \pm 0.129^{\mathrm{Ab}}$ & $2.04 \pm 0.109$ & $5.30 \pm 0.0688^{\mathrm{ABac}}$ & $10.39 \pm 0.074 \mathrm{Aac}$ & $3.81 \pm 0.016$ & 39 & $13.79 \pm 0.815$ \\
\hline 4 & 44 & $3.49 \pm 0.147 \mathrm{ab}$ & $2.22 \pm 0.124$ & $5.55 \pm 0.076^{\mathrm{Bb}}$ & $10.01 \pm 0.082^{\mathrm{Bb}}$ & $3.52 \pm 0.129$ & 33 & $13.16 \pm 0.849$ \\
\hline $5+$ & 48 & $3.46 \pm 0.146^{\mathrm{ab}}$ & $2.24 \pm 0.123$ & $5.54 \pm 0.076^{\mathrm{Bbc}}$ & $10.15 \pm 0.082^{\mathrm{ABbc}}$ & $3.50 \pm 0.129$ & 34 & $12.84 \pm 0.868$ \\
\hline $\begin{array}{l}\text { Calving } \\
\text { Season }\end{array}$ & & NS & NS & NS & 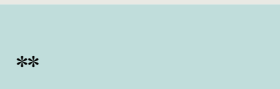 & NS & & NS \\
\hline 1 (Spring) & 88 & $3.11 \pm 0.121$ & $2.23 \pm 0.102$ & $5.42 \pm 0.065$ & $10.48 \pm 0.071^{\mathrm{Aa}}$ & $3.77 \pm 0.111$ & 62 & $12.34 \pm 0.760$ \\
\hline 2 (Summer) & 57 & $3.52 \pm 0.167$ & $1.90 \pm 0.141$ & $5.36 \pm 0.087$ & $10.07 \pm 0.094^{\mathrm{Bb}}$ & $3.47 \pm 0.148$ & 27 & $12.87 \pm 1.101$ \\
\hline 3 (Autum) & 133 & $3.45 \pm 0.113$ & $2.08 \pm 0.096$ & $5.40 \pm 0.061$ & $10.19 \pm 0.066^{\mathrm{Bb}}$ & $3.62 \pm 0.103$ & 86 & $14.29 \pm 0.779$ \\
\hline 4 (Winter) & 154 & $3.35 \pm 0.098$ & $2.26 \pm 0.083$ & $5.42 \pm 0.053$ & $10.33 \pm 0.057^{\mathrm{Bb}}$ & $3.73 \pm 0.089$ & 90 & $12.48 \pm 0.643$ \\
\hline Lactation & & & & & & & & \\
\hline Stage & & NS & $* *$ & NS & *** & NS & & ** \\
\hline $1(\leq 100 d)$ & 93 & $3.53 \pm 0.132$ & $1.86 \pm 0.111^{\mathrm{Aa}}$ & $5.36 \pm 0.071$ & $10.11 \pm 0.077^{\mathrm{Aa}}$ & $3.70 \pm 0.121$ & 61 & $15.62 \pm 0.878^{\mathrm{Aa}}$ \\
\hline $2(101-200 \mathrm{~d})$ & 134 & $3.26 \pm 0.121$ & $2.24 \pm 0.102^{\mathrm{ABbc}}$ & $5.39 \pm 0.064$ & $10.21 \pm 0.069^{\mathrm{ABab}}$ & $3.52 \pm 0.109$ & 74 & $12.89 \pm 0.834^{\mathrm{ABab}}$ \\
\hline $3(201-300 d)$ & 81 & $3.24 \pm 0.131$ & $2.39 \pm 0.111^{\mathrm{Bb}}$ & $5.43 \pm 0.069$ & $10.46 \pm 0.075^{\mathrm{Bb}}$ & $3.73 \pm 0.118$ & 42 & $13.22 \pm 0.801^{\mathrm{ABab}}$ \\
\hline $4(301-400 \mathrm{~d})$ & 62 & $3.42 \pm 0.141$ & $1.90 \pm 0.119 \mathrm{ABac}$ & $5.36 \pm 0.075$ & $10.20 \pm 081^{\mathrm{ABab}}$ & $3.61 \pm 0.126$ & 52 & $11.45 \pm 0.847^{\mathrm{Bb}}$ \\
\hline $5(>400 d)$ & 62 & $3.34 \pm 0.135$ & $2.19 \pm 0.114^{\mathrm{ABab}}$ & $5.48 \pm 0.070$ & $10.35 \pm 0.076^{\mathrm{ABb}}$ & $3.68 \pm 0.120$ & 36 & $11.45 \pm 0.887^{\mathrm{Bb}}$ \\
\hline TEHS & & & & $* *$ & NS & NS & & NS \\
\hline 1 & 75 & - & - & $5.25 \pm 0.061^{\mathrm{Aa}}$ & $10.25 \pm 0.066$ & $3.66 \pm 0.103$ & 48 & $12.80 \pm 0.702$ \\
\hline 2 & 234 & - & - & $5.24 \pm 0.042^{\mathrm{Aa}}$ & $10.27 \pm 0.046$ & $3.63 \pm 0.072$ & 145 & $13.19 \pm 0.464$ \\
\hline 3 & 97 & - & - & $5.50 \pm 0.057^{\mathrm{Bb}}$ & $10.31 \pm 0.062$ & $3.57 \pm 0.097$ & 60 & $13.86 \pm 0.664$ \\
\hline 4 & 26 & - & - & $5.62 \pm 0.096^{\mathrm{Bb}}$ & $10.23 \pm 0.103$ & $3.74 \pm 0.016$ & 12 & $12.14 \pm 1.301$ \\
\hline BDS & & & & NS & NS & NS & & NS \\
\hline $1-2$ & 106 & - & - & $5.34 \pm 0.059$ & $10.16 \pm 0.064$ & $3.60 \pm 0.100$ & 75 & $12.95 \pm 0.687$ \\
\hline 3 & 153 & - & - & $5.36 \pm 0.054$ & $10.25 \pm 0.059$ & $3.73 \pm 0.39$ & 82 & $12.18 \pm 0.666$ \\
\hline 4 & 110 & - & - & $5.48 \pm 0.057$ & $10.24 \pm 0.062$ & $3.60 \pm 0.96$ & 69 & $13.06 \pm 0.664$ \\
\hline 5 & 63 & - & - & $5.44 \pm 0.070$ & $10.32 \pm 0.076$ & $3.66 \pm 0.118$ & 39 & $13.79 \pm 0.862$ \\
\hline Overall & 432 & $3.30 \pm 0.048$ & $2.17 \pm 0.038$ & $5.22 \pm 0.024$ & $10.14 \pm 0.032$ & $3.58 \pm 0.039$ & 265 & $13.92 \pm 0.315$ \\
\hline
\end{tabular}

NS: non significance, *: $P<0.05$, ${ }^{*}: P<0.01$. A, B, C,D: different letter shows significant differences between the groups for $P<0.01 . a, b, c, d, e$ : different letter shows significant differences between the groups for $P<0.05$.

The effect of farm and parity on BDS were found statistically significant $(\mathrm{P}<0.01)$. However, the effects of calving season and lactation stage were found not significant $(\mathrm{P}>0.05)$ and the overall mean was 3.30 \pm 0.048 . 
In this study, the lowest BDS was $2.10 \pm 0.252$ in Farm 4 and this represented the cleanest cows among the farms. The highest score was $4.64 \pm 0.165$ in Farm 9 representing the dirtiest cows reared in this farm.

According to the parity, the lowest BDS (3.08 \pm 0.093) was found in primiparous cows and the highest score $(3.52 \pm 0.129)$ was remarked in cows at the $3^{\text {rd }}$ parity (Table 1 ). The study subjects related to BDS in dairy cows are not abundant. In this study, no farm was found with BDS 1 . The overall BDS found here $(3.30 \pm 0.048)$ in a 5 based scoring scale was higher than the results of Sandrucci et al. (2014) who found 1.77, 2.42 and 1.95, Dohmen et al. (2010) with 2.76, 2.40 and 2.54, Erden and Okuyucu (2019) with 1.57, 2.16 and 1.49 of means, respectively for the udder, real leg and flanc BDS in a four based scale. In a study, it was reported a significant lower level of milk constituents in milk samples from buffalo scored 4 of BDS in a 4 based scale. It can be concluded that the hygienic conditions have to be ameliorated in all visited farms. However, the cleaning of the shelter and the provision of clean woodchips are taken as the management conditions helping to keep cows clean (O’Driscoll et al., 2008).

\section{Teat end byperkeratosis score (TEHS)}

For the TEHS, the effect of farm $(\mathrm{P}<0.01)$, parity ( $\mathrm{P}$ $<0.05)$ and lactation stage $(\mathrm{P}<0.01)$ were found to be statistically significant but the calving season was not significant $(\mathrm{P}>0.05)$. The overall mean was found to be $2.17 \pm 0.038$. According to farms, the lowest average was $1.80 \pm 0.312$ in Farm 2 corresponding to the cows with well formed teat ends. The highest average was $2.70 \pm 0.140$ in Farm 9 corresponding to the farm having cows with deformed teat ends that was also the highest milk producing farm per cow (Table 1).

According to the literature, the level of TEHS depends on farm conditions, high vacuum of milking machines and farm management especially on the farm level. On the cow level, the breed, genetic, cow's age (Sieber and Farnsworth, 1981; Shearn and Hillerton, 1996; Neijenhuis et al., 2001) and the parity (Emre, 2009) are likely to affect the level of TEHS. Regarding the parity, it was found the low average of TEHS in primiparous $(1.92 \pm 0.079)$ cows. It increased with the parity and reached the highest average $(2.24 \pm 0.123)$ in $5^{\text {th }}$ and higher parities (multiparous). The different changes in averages according to parity were presented on Figure 1. In this situation, the results correspond to expected results as stated by Emre (2009) saying that the teat end hyperkeratois increases with parity. In addition, the parity also influences the increase of the teat end hyperkeratosis (Shearn and Hillerton, 1996; Neijenhuis et al., 2001).

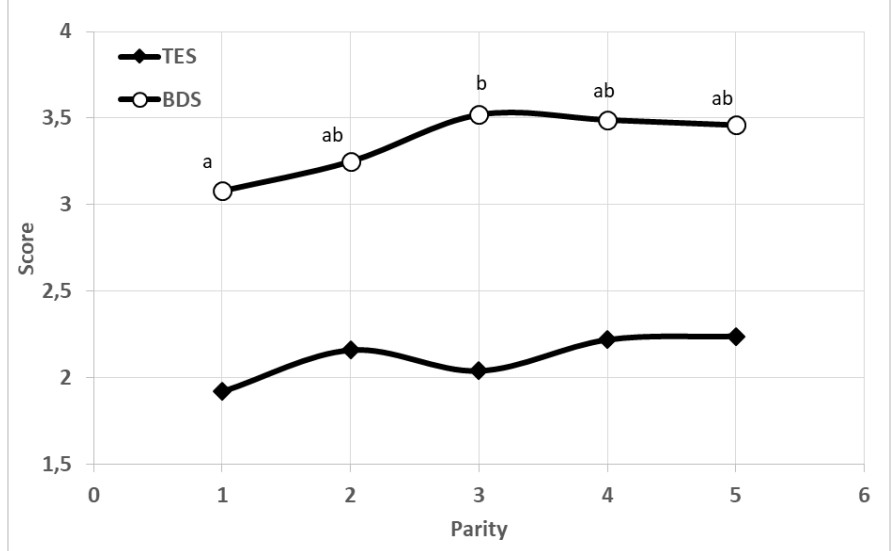

Figure 1: Evolution of body dirtines score (BDS) and teat end score (TES) or teat end hyperkeratosis score (TEHS) in HF cows depending on parity ( $a, b$ : different letter shows significant differences between the groups for $P<0.05$ ).

According to lactation stage, the cows at the $1^{\text {st }}$ stage were found with the lowest level of TEHS (1.86 \pm $0.111)$ whereas the highest average $(2.39 \pm 0.111)$ was found in cows at the $3{ }^{\text {rd }}$ stage. However, the TEHS did not increase progressively with the lactation stages. The results found here correspond to expected results as stated by Shearn and Hillerton (1996), Neijenhuis et al. (2001) saying that the TEHS begins to increase at the peak lactation and continues to increase till the end of lactation. The statement of those researchers is similar to the explanation of Francis (1984) saying that the increased TEHS begins to be observed from the fourth month of lactation. During this study, it was observed the flow of milk in cows at the end of lactation were ready to be dried. This means that there was sphyncter defect due to the high level of TEHS and such cows had higher score.

\section{Morning milk yield (MMY)}

For MMY, the farm and lactation stage effects were statistically significant $(\mathrm{P}<0.01)$. Other effects such as parity, calving season, BDS and TEHS were not significant $(\mathrm{P}>0.05)$. The overal mean of $\mathrm{MMY}$ was $13.92 \pm 0.315 \mathrm{~kg}$.

In this study, regarding farm effect, the highest average was $17.27 \pm 0.917 \mathrm{~kg}$ in Farm 9 and the lowest average was found to be $7.67 \pm 0.920 \mathrm{~kg}$ in Farm 5 . 
Also, the MMY was higher in the first lactation stage and decreased progressively with advanced lactation. In this study, the mean of MMY found here (13.92 $\pm 0.315 \mathrm{~kg}$ ) was similar to the result of Koç (2007a) who found in his study an average of $13.20 \pm 0.529$ $\mathrm{kg}$ MMY in HF. This average was higher than the results of Koç (2007b) with $8.92 \pm 0.188 \mathrm{~kg}$, Koç and Kizilkaya (2009) with $8.92 \pm 0.183 \mathrm{~kg}$ and Koç (2011) with $7.69 \pm 0.397 \mathrm{~kg}$ of average. It was also observed that the milk yield, as expected, was higher in the first lactation stage but decreased progressively with advanced of lactation. This situation corresponds to the theories as it is well known that milk yield increase progressively till the peak lactation comprehended in the fist lactation stage and decrease progressively untill when the cow is dry.

\section{Milk quality traits}

Milk fat content (FC): In this study, only farm effect on $\mathrm{FC}$ was statistically significant $(\mathrm{P}<0.01)$ whereas other effects were found not important $(\mathrm{P}>0.05)$. The overall mean was found to be $3.58 \pm 0.039 \%$ with $3.04 \pm 0.095 \%$ as the lowest average in Farm 6 and $4.21 \pm 0.318 \%$ as the highest average in Farm 2 in this study. The changes in milk FC could be explained by nutritional features and the farm management. The great key to get good results in milk FC is to feed cows with $>35 \%$ of the ration being forage or forage quantity reaching $1.5 \%$ of body weight.

Non-fat dry matte content (NFDMC): The effects of farm, parity, calving season and lactation stage on milk NFDMC were statistically significant $(\mathrm{P}<0.01)$. However, the BDS and TEHS were not significant $(\mathrm{P}>0.05)$ and the overall mean was $10.14 \pm 0.032 \%$. Considering the farm effect, the lowest average was $9.48 \pm 0.098 \%$ in Farm 5 while the highest average was $10.90 \pm 0.117 \%$ in Farm 7 .

According to the parity, the NFDMC averages were higher in the first 3 parities and were lower in $4^{\text {th }}$ and higher parities. In this study, it can be confirmed that milk NFDMC decreased with the parity.

As far as the the calving season effect is concerned, it was higher $(10.48 \pm 0.071 \%)$ in cows that calved in spring and decreased in summer with $10.07 \pm$ $0.094 \%$. It also increased in the following seasons to reach $10.19 \pm 0.066 \%$ in autum and $10.33 \pm 0.057 \%$ in winter. For lactation stage, the averages were higher in the $3^{\text {rd }}$ lactation stage with $10.46 \pm 0.075 \%$ of average.
The overall NFDMC average (10.14 \pm 0.032\%) found in this study was similar to the result of Koç (2007a) who found $9.98 \pm 0.99 \%$ fof $45 \mathrm{HF}$ cows raised in some dairy farms in Aydın Province during the morning milk samples. It was found higher than Koç (2007b) with $9.61 \pm 0.048 \%$ of average in HF; higher than Koç (2008) with $9.78 \pm 0.024 \%$ of average in HF, Koç (2011) with $8.23 \pm 0.067 \%$ in HF, Koç (2015) with $8.78 \pm 0.044 \%$ in RH.

Milk somatic cell count $\left(\log _{10} \mathrm{SCC}\right)$ : In this study, the effect of farm, parity and TEHS were statistically significant $(P<0.01)$ while the calving season, lactation stage and BDS were not significant $(\mathrm{P}>0.05)$. The $\log _{10}$ SCC average was $5.22 \pm 0.024$ becoming 165 958 cells / $\mathrm{ml}$ taken backward. Considering the farms, the lowest average was $5.21 \pm 0.137 \approx 162181$ cells / $\mathrm{ml}$ in Farm 4 and the highest average was found to be $5.79 \pm 0.081 \approx 616595$ cells / $\mathrm{ml}$ in Farm 3 .

According to the parity, primiparous cows had lower $\log _{10} \operatorname{SCC}(5.25 \pm 0.054)$ but increased with the parity to reach the highest average $(5.55 \pm 0.076)$ in cows at $4^{\text {th }}$ and higher parities.

These results correspond to expected results. According to the literature, the increase in milk SCC corresponds to the decrease in milk yield and the incidence of clinical or subclinical mastitis. In addition, the increased SCC according to the parity obeys to the confirmation of Göncü and Özkütük (2002) who stated that the increase in SCC was observed according to the parity. This situation corresponded also to the increase of mastitis incidence in advanced lactations in dairy cows (Izgür, 1984). The significance of the SCC according to the parity was also confirmed by Topaloğlu and Güneş (2005) who found a significant effect $(\mathrm{P}<0.05)$ of parity according to the average of $\mathrm{SCC}$ in the milk in $\mathrm{HF}$ cows.

In this study, the TEHS effect on $\log _{10} \mathrm{SCC}$ was highly significant $(\mathrm{P}<0.01)$. The $\log _{10} \mathrm{SCC}$ means of cows scored TEHS 1 and 2 were $5.25 \pm 0.061$ and $5.24 \pm 0.042$, respectively. In this case, those cows are accapted to be very healthy in terms of teat end profile. What is more, $\log _{10} \mathrm{SCC}$ averages were higher in cows scored TEHS 3 and 4 with the highest average $5.62 \pm 0.096$ for TEHS 4 (Table 1 ). With these results, it can be concluded that the SCC increased as the TEHS increased (Figure 2). In fact, these results correspond exactely to the expected 
results and sustain the aim of this study.

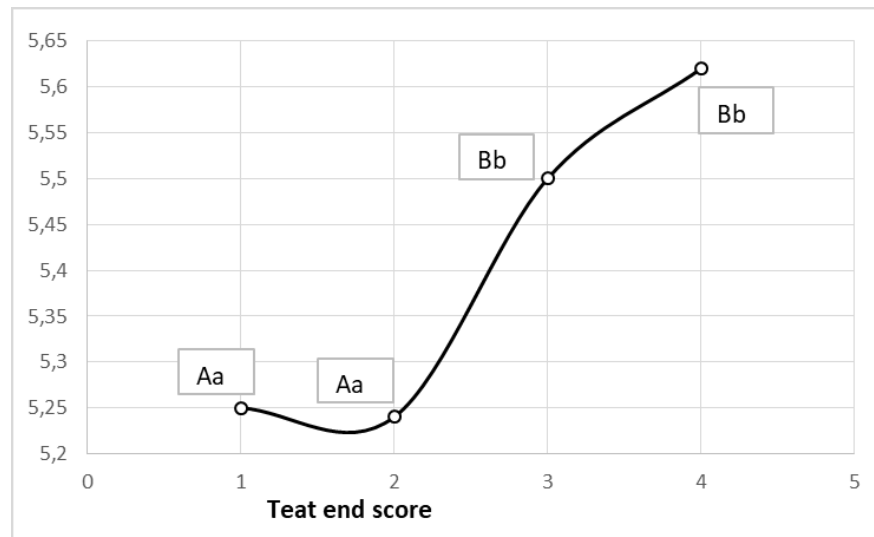

Figure 2: Evolution of somatic cell count $\left(\log _{10} S C C\right)$ according to teat end hyperkeratosis score (A,B: different letter shows significant differences between the groups for $P<0.01, a, b$ : different letter shows significant differences between the groups for $P<0.05$ ).

In this study, the overall average milk SCC found here, 165958 cells / ml, was similar to the average found by $\mathrm{Ng}$-Kwai-Hang et al. (1984) whose study was aimed at comparing the variation in milk SCC according to the age in two groups of cows (166 000 cells / ml). It was also similar to Koç (2011) who found 199 022 cells / $\mathrm{ml}$ and 138644 cells / $\mathrm{ml}$ respectively in summer and winter with 168833 cells / $\mathrm{ml}$ of average in both seasons in $\mathrm{HF}$ and $\mathrm{MB}$ cows.

It was also higher than Koç (2009) who performed a study aimed at comparing the SCC in the milk of cows that calved in winter by morning and evening milking (133 265 cells / ml). Also higher than Topaloğlu and Güneş (2005) who found 138000 cells/ml; higher than Yilmaz (2010) who found 63753 cells / $\mathrm{ml}$ in Red-Holstein in his study. It was also higher than Koç (2015) who found 91833 cells / ml and 100462 cells / $\mathrm{ml}$ in his study during morning and evening milkings, respectively.

In this study, the significant effect of the TEHS on $\log _{10}$ SCC was sustained by Francis (1984) who found an increased TEHS during the fourth month of lactation and a relationship of the TEHS with an increased number of SCC. Michel et al. (1974) also suggested that the increased TEHS correlates with the increased mastitis incidence risks. As observed in the results of this study, the effect of the BDS on $\log _{10} \mathrm{SCC}$ was not significant $(\mathrm{P}>0.05)$.

\section{Correlations}

The correlation coefficients between the traits are presented in Table 2. The calculated correlations are generally weak and the highest correlation was estimated between $\log _{10} \mathrm{SCC}$ and TEHS ( $\mathrm{r}=0.24$; $\mathrm{P}<0.01)$. The correlation of NFDMC with BDS $(\mathrm{r}=$ -0.22, $\mathrm{P}<0.01)$ and MMY $(\mathrm{r}=-0.22, \mathrm{P}<0.01)$ were negative, however its correlation with $\log _{10} \mathrm{SCC}$ is positive $(r=0.14, \mathrm{P}<0.01)$. As expected, MMY had a negative correlation with FC $(r=-0.20, \mathrm{P}<0.01)$, but its correlation with BDS was positive $(r=0.18$, $\mathrm{P}<0.01)$. Comparatively to the previous studies, it has been reported a season effect of BDS on SCC. During the spring and summer, it was found a high correlation coefficient $r=0.53$ between BDS and SCC but there was no significant effet in other seasons (Erden and Okuyucu, 2019). That fact can explain the insignificance of the BDS on SCC found in this study processed in autumn and winter seasons. The current results of this study were similar to the results of Bulu and Erdem (2019) who found very weak correlation coefficients between BDS and SCC in milk samples of buffalos $r=0.037,0.052$ and 0.016 , for the udder, rear leg and flanc hygiene scores, respectively.

Table 2: Correlation coefficients among teat end score (TEHS), body dirtines score (BDS), somatic cell count $\left(\log _{10} S C C\right)$, non-fat dry matter content (NFDMC), fat content (FC) and morning milk yield (MMY).

$\begin{array}{llllll} & \text { BDS } & \log _{10} \text { SCC } & \text { NFDMC } & \text { FC } & \text { MMY } \\ \text { TEHS } & 0.08 & 0.24^{* *} & -0.06 & 0.01 & 0.07 \\ \text { BDS } & & 0.07 & -0.22^{* *} & 0.02 & 0.18^{* *} \\ \log _{10} \text { SCC } & & & 0.14^{* *} & -0.002 & -0.11 \\ \text { NFDMC } & & & & 0.17^{* *} & -0.22^{* *} \\ \text { FC } & & & & & -0.20^{* *}\end{array}$

**: $P<0.01$.

\section{Conclusions and Recommendations}

This study was focussed on the determination of BDS and TEHS effects on milk yield and quality in $\mathrm{HF}$ cows. The results of this study showed that only the farm and the parity had a significant effect on the BDS while the farm, parity and lactation stage had a significant effect on the TEHS. Those results showed that in order to attenuate both the degree of BDS and TEHS, the farm management and the amelioration of hygienic conditions of the barn have to be taken into account especially in lactating cows.

In this study, only the TEHS significantly affected the milk SCC. Other milk quality traits and MMY were not affected by the TEHS. However, the BDS 
had no effect neither on milk yield, nor on quality traits. According to the aim of the present study, the results showed that the milk SCC increased with the TEHS. This means that the evaluation of the TEHS can help to assess the milk quality without proceeding to laboratory analysis. The TEHS could be used to estimate the level of SCC in milk samples, this could help to identify the emerging problem that may occur in lactating cows and could help to early identify and prevent subclinical and clinical mastitis. As recommandations, a routine teat condition control and teat scoring might be practised especially two or three times within a lactation. In addition, the farmers might regularly control milking machines, have to avoid overmilking and might take care of cows entering the dry period. As the milk quality is the major concern of milk producers, dairy entreprises and milk consumers, the current study showed the role played by the control of teat conditions in $\mathrm{HF}$ cows.

\section{Acknowledgements}

The special thanks are addressed to various people and support organisation for their valuable support, data collection, laboratory and data analysis.

\section{Novelty Statement}

This research helped a lot in the livestock sector by showing the impact of hyperkeratosis level on milk somatic cell count. The higher is the teat end hyperkeratosis, the higher is the somatic cell count in the milk. That is why the control of teat end hyperkeratosis is very important

\section{Author's Contribution}

All the authors contributed to the realisation of this paper by harvesting data on the field and by analyzing the results and writing the literature

\section{Conflict of interest}

The authors have declared no conflict of interest.

\section{References}

Akman, N., Yener, S.M., Cedden, F. and Şen, A.Ö., 2015. Cattle rearing in Turkey; situation, changes and insights. Turkey Agricultural Engineering VIII. Technical Congress. Ankara.
Baştan, A., 2010. Udder Health and Problems in Cows. Kardelen Press. Inonu Avenue, Ankara.

Blowey, R. and Edmondson, P., 1995. Mastitis control in dairy herds. United Kingdom: Farming Press.

Bulu, A. and Erdem, H., 2019. Relationships of body hygiene scores and udder $\mathrm{S}$ surface temperature with milk somatic cell count and milk components in anatolian buffaloes. Efficient Production for the World. 18-20 Septembre 2019. Istanbul, Turkey.

Butor, N., 2019. L'histoire complexe de la domestication de la vache. https:/wwww. pourlascience.fr/sd/evolution/lhistoirecomplexe-de-1a-domestication-de-1avache-17580.php (accessed 23.5.2020).

Dohmen, W., Neijenhuis, F. and Hogeveen, H., 2010. Relationship between udder health and hygiene on farms with an automatic milking system. J. Dairy Sci., 93(9): 4019-4033. https:// doi.org/10.3168/jds.2009-3028

EAS, 164, 2006. Determination of fat content (Routine method). Second Edition 2006. https://1aw.resource.org/pub/eac/ibr/ eas.164.2006.pdf (accessed 20 may 2020)

Emre, B., 2009. Distrubition of lesions occured in teat skin and orifice and their effects on somatic cell counts of milk in cattle Ankara University, Institute of Health Sciences, Ankara, Turkey.

Erdem, H. and Okuyucu, I.C., 2019. Influence of hygiene status of cows on somatic cell count and milk components during summer season. H. Erdem et al. Large Anim. Rev., 25: 7-10.

Francis, P.G., 1984. Teat skin lesions and mastitis. Br. Vet. J., 5: 430-436. https://doi. org/10.1016/0007-1935(84)90036-8

Göncü, S. and Özkütük, K., 2002. Factors effective at somatic cell count (SCC) in the milk of Black and White cows kept in intensive dairy farms at Adana Province and their relationships with mastitis. J. Anim. Prod., 43: 44-53.

Izgür, H., 1984. Predispose factors of mastitis I. Mastitis Seminar, Ankara University, Faculty of Veterinary Ankara, pp. 17-29.

Koç, A., 2007a. A research on milk fat content, nonfat dry matter content and somatic cell count of Mombeliarde ve Holstein-Friesian cows Dary Cattle Semposium of Turkey. Proc. Book, pp. 386-394.

Koç, A., 2007b. Daily milk yield, non-fat dry matter content and somatic cell count of 
Holstein-Friesian and Brown-Swiss cows. Acta Vet. Beograd, 57(5-6): 523-535. https://doi. org/10.2298/AVB0706523K

Koç, A., 2008. Factors influencing daily yield, somatic cell count and non-fat dry matter content of milk. Indian Vet. J., 85: 630-632.

Koç, A., 2009. A research on milk yield, milk constituents and reproductive performances of Holstein Friesian and Montbeliarde cows. $\mathrm{XVII}^{\text {th }}$ International Congress of Femesprum, Mediterranean Federation of Health and Production of Ruminants, May 27-30, 2009 Perugia, Italy.

Koç, A. and Kızılkaya, K., 2009. Factors influencing test day milk yield of Holstein-Friesian cows. J. Anim. Prod., 50(1): 24-30.

Koç, A., 2011. A study of the reproductive performance, milk yield, milk constituents and somatic cell count of Holstein-Friesian and Montbeliarde cows. Turk. J. Vet. Anim. Sci., 35(5): 295-302.

Koç, A., 2015. Effects of somatic cell count and various environmental factors on milk yield and foremilk constituents of Red-Holstein cows. Tarım Bilimleri Dergisi., 21(3): 439-447. https://doi.org/10.15832/ankutbd.25135

Mein, G.A., Neijenhuis, F., Morgan, W.F., Reinemann, D.J., Hillerton, J.E., Baines, J.R., Ohnstad, I., Rasmussen, M.D., Timms, L., Britt, J.S., Farnsworth, R., Cook, N. and Hemling, T., 2001. Evaluation of bovine teat condition in commercial dairy herds: 1 . Noninfectious factors. Proc $2^{\text {nd }}$ Int. Symp. Mastitis Milk Quality, NMC/AABP, Vancouver, pp. 347-351.

Michel, G., Seffner, W. and Schulz, J., 1974. Hyperkeratosis of teat duct epithelium in cattle. MH Vet. Med., 29: 570-574.

Mundan, D., Meral, B., Demir, A. and Doğaner, M., 2015. Evaluation an economic of total bacteria and somatic cell count in dairy cattle farms. Harran Univ. J. Vet. Fac., 4: 84-89.

Ndihokubwayo, F., Koç, A. and Uzun, N., 2019. Teat profile and its importance in dairy cows. $11^{\text {th }}$ Animal Science Conference, Cappadocia. Section II: Animal breeding and genetics. J. Anim. Sci. Prod., October 2019: 316-322.

Neijenhuis, F., Mein, G.A., Britt, J.S., Reinemann, D.J.,Hillerton,J.E., Farnsworth, R., Baines,J.R., Hemling, T., Ohnstad, I., Cook, N., Morgan, W.F. and Timms, L., 2001. Evalution of bovine teat condition in commercial dairy herds: 4. Relationship between teat-end callosity or hyperkeratosis and mastitis. In Proceedings of the Second International Symposium on Mastitis and Milk Quality, (Mein, G.A.), Teat Club International, c/o F. Neijenhuis, Research Institute for Animal Husbandry Lelystad, The Netherlands Authors from: The Netherlands, Australia, USA, UK. pp. 362-366.

Ng-Kwai-Hang, K.F., Hayes, J.F., Moxley, J.E. and Monardes, H.G., 1984. Variability of test day milk production and relation of somatic cell counts with yield and compositional change of bovine milk. J. Dairy Sci., 67: 361-366. https:// doi.org/10.3168/jds.S0022-0302(84)81309-0

NMC, 1968. Direct microscopic somatic cell count in milk. subcommitee on screening tests, national mastitis council. J. Milk Food Technol., 31(11): 350-354. https://doi.org/10.4315/0022-274731.11 .350

O’Driscoll, K., Boyle, L., French, P., Meaney, B. and Hanlon, A. 2008. The effect of out-wintering pad design on dirtiness score, somatic cell score and mastitis incidence in dairy cows. Animal, 2(6): 912-920. https://doi.org/10.1017/ S1751731108001882

Sandrucci, A., Bava, L., Zucali, M. and Tamburuni, A., 2014. Management factors and cow traits influencing milk somatic cell counts and teat hyperkeratosis during different seasons. R. Bras. Zoot.,43(9): 505-511. https://doi.org/10.1590/ S1516-35982014000900008

SAS, 1999. Statistical Analysis System User' Guide Statistics. SAS Institute Inc. Cary NC 27513 USA.

Shearn, M.F.H. and Hillerton, J.E., 1996. Hyperkeratosis of the teat duct orifice in the dairy cow. J. Dairy Res., 63: 525-532. https:// doi.org/10.1017/S0022029900032064

Sieber, R.L. and Farnsworth, R.D., 1981.Prevalence of chronic teat end lesions and their relationship to intramammary infections in 22 herds of dairy cattle.J. Am. Vet. Med. Assoc., 178: 1263-1267.

Topaloğlu, N. and Güneş, H., 2005. Researhes on milk yield traits of Holstein Frieasin in the United Kingdom. Istanbul Univ. J. Vet. Fac., 31: 99-119.

Y1lmaz, H., 2010. A research on milk production and milk quality traits of Red Holstein. MSc. thesis. ADU Graduate School Of Natural And Applied Sciences, Aydın, Turkey. 